\title{
Assessing the completeness of bryophytes inventories: an oceanic island as a case study (Terceira, Azorean archipelago)
}

\author{
Silvia C. Aranda • Rosalina Gabriel • Paulo A. V. Borges • \\ Jorge M. Lobo
}

Received: 4 December 2009/Accepted: 16 April 2010/Published online: 1 May 2010

(C) Springer Science+Business Media B.V. 2010

\begin{abstract}
How useful, complete or unbiased are comprehensive databases in order to provide reliable estimations of diversity? Using compiled data from bryophytes in Terceira Island (Azores), we specifically aim (1) to describe the register of species over time, (2) to assess the inventory completeness, i.e., the ratio between the observed and the maximum expected species, and (3) to locate the most promising areas for further surveys. First, each new recorded species was plotted against its collecting year, using the number of databaserecords as a surrogate of survey effort, to get the accumulation curves. These curves were then extrapolated to obtain the theoretical number of existing species according to Clench and exponential models. Spatial and habitat characteristics of the recorded taxa were also explored. Our results show an increasing trend in the rate of recorded species (c. five species per year), as well as a maximum of around a third of the theoretically "real" number of expected species that could yet remain unknown. Nevertheless, predictions of species richness were highly variable depending on the fitting curve used. Survey effort was similar between liverworts and mosses, as were inventory completeness values, but the rate of new recorded species was higher for mosses. Although bryologists visited preferably native habitats, we show that new species citations may also be found in modified habitats (e.g., exotic forests and semi-natural grasslands). We conclude that the analysis of extensive databases is a useful tool in revealing the recording and taxonomic gaps, further showing that bryophyte inventories could still be incomplete in Terceira Island. A strategy on how to improve species' collections in remote areas is suggested, hoping to contribute to all-inclusive biodiversity studies in the Azores and elsewhere.
\end{abstract}

Electronic supplementary material The online version of this article (doi:10.1007/s10531-010-9854-5) contains supplementary material, which is available to authorized users.

S. C. Aranda $(\bowtie) \cdot$ R. Gabriel · P. A. V. Borges

Azorean Biodiversity Group-CITA-A, Departamento Ciências Agrárias, Universidade dos Açores, 9701-851 Angra do Heroísmo, Portugal

e-mail: mcnsc850@mncn.csic.es

S. C. Aranda - J. M. Lobo

Departamento de Biodiversidad y Biología Evolutiva, Museo Nacional de Ciencias Naturales (CSIC), C/José Gutiérrez Abascal, 2, 28006 Madrid, Spain 
Keywords Biological databases $\cdot$ Collecting bias $\cdot$ Laurisilva $\cdot$ Liverworts · Macaronesia $\cdot$ Mosses $\cdot$ Sampling efficiency $\cdot$ Species accumulation curves

\section{Introduction}

Compiling taxonomic information and distribution data are still the basis for most biodiversity studies. What originally started as a matter of scientific interest is today an undeniable need, due to the rapid and irreversible decline of biodiversity, mainly caused by habitat fragmentation and alteration (Pimm and Raven 2000). Having access to reliable biodiversity values is a key issue when defining conservation priority areas and policies. Therefore, it is important to acknowledge not only how much we know, but also how much has yet to be discovered. We have been attempting to answer this question for years (May 1988, 1990; Wilson 1988; Scotland and Wortley 2003; Bebber et al. 2007) and we have not yet managed to provide reliable estimates for many taxa, especially for hyperdiverse groups such as arthropods and other small organisms (e.g., Gaston 1991, 1996; Curtis et al. 2002). Consequently, finding the most effective way to gather taxonomic information is an urgent task for both theoretically and applied purposes.

The inventorying efforts of different biologists results in a number of checklists and census catalogues which are the obvious starting point of many current biodiversity studies (e.g., Mueller et al. 2007). Nevertheless, biologists have typically been attracted to places where there is greater diversity or to particular localities where they expect to find more taxonomic singularities (endemics, rare species, species of conservation concern, etc.). There are few records of where species were looked for but not found, i.e., sites with recorded and reliable absences (but see standardized ecological studies). Numerous examples exist where the maps of diversity generated with census information do not show the real distribution of species but, instead, they represent the maps of collections that were conducted according to their cultural or landscape interest, or for accessibility reasons (Kadmon et al. 2004; Pautasso and McKinney 2007; Sánchez-Fernández et al. 2008).

Although quantifying diversity through a single, comparable measure presents difficulties and limitations (Gotelli and Colwell 2001), species richness seems to be widely accepted as a surrogate of diversity (Magurran 2004). The problem is that, for diverse taxa, the number of recorded species will increase as more survey effort is conducted. Moreover, even when the same effort has been made across sites or time periods, valid comparisons are only possible once the maximum number of species has been reached, or alternatively, when some sort of standardized sampling is performed (see Borges et al. 2009). Since it is well accepted that the observed richness underestimates the real number of species, different equations have been proposed to estimate the theoretical value of "real" species richness (Soberón and Llorente 1993; Colwell and Coddington 1994; Walther and Moore 2005; Hortal et al. 2006). The ratio between these two values, observed and estimated richness, may then be used as a measure of 'completeness' of the inventories (Soberón et al. 2000) or 'sample coverage' (Brose et al. 2003). Thus, assessing the quality of primary data based on the inventory completeness informs us about the current state of knowledge and also on how much we do not know. Once we have those estimates, the main issue at hand is to identify geographical gaps of information and to effectively minimise them.

In this study, we intend to analyse the historical process of bryophyte inventory on Terceira Island (Azorean archipelago), estimate the proportion of species yet to be discovered, and offer guidelines to efficiently direct future surveys. The Azores are included 
in the Macaronesian region, and its flora is considered part of the subtropical vegetation that originally covered most of Western Europe during the Tertiary period surviving Pleistocene glaciations. As a consequence, it is often believed that much of the flora and fauna of that time are a relict in this area (but see Vanderpoorten et al. 2007; Rull 2008), which has led the islands to be included in one of the 25 world biodiversity hotspots (the Mediterranean Basin) (Médail and Quézel 1999; Myers et al. 2000). Bryophytes are a representative example of such past conditions, as evidenced by their luxuriant growth in the humid evergreen laurel forests (Gabriel and Bates 2005). Despite their ecological and evolutionary importance, bryophytes have traditionally received less attention than other plants, and a few bryologists have already published works focusing on the completeness of distribution inventories and the location where gaps of information are expected (Callaghan and Ashton 2008). Thanks to the pioneering efforts of many bryologists, the bryoflora described for Europe is well known (see compilation in Hill et al. 2006; Söderström et al. 2007). For the specific case of the Macaronesian region, a number of recently published studies (Gabriel et al. 2005; González-Mancebo et al. 2008; Sérgio et al. 2008) have provided relatively complete lists of species (see Table 1). However, with some exceptions (e.g., Casas et al. 1985, 1989, 1992, 1996; Hill et al. 1991-1994; von Konrat et al. 2008), few attempts have been made to compile bryophyte distributional data. The promoters of recent initiatives such as the global GBIF project (http://www.gbif.org/), the TROPICOS plant database (http://www.tropicos.org) and the ELPT project (http:// www.early-land-plants-today.org/) are working to overcome this knowledge deficit by making species information available on the Internet. For the Azorean archipelago, all the known data from the literature, herbaria, public and private collections and unpublished datasets is digitised in the ATLANTIS-Tierra 2.0 software (Zurita and Arechavaleta 2003) using a UTM grid-system of $500 \mathrm{~m} \times 500 \mathrm{~m}$ resolution. This program was crucial to the development of the Azorean Biodiversity Portal in 2008 (http://www.azoresbioportal. angra.uac.pt/), which presently shares with the general public the known distributional data of most of the Azorean terrestrial taxa.

Using a comprehensive database of bryophytes' distribution in Terceira Island, the specific aims of this study were: (1) to describe the historical development of bryophyte inventorying, comparing also the rates of new recorded species among taxonomical groups, (2) to estimate the degree of inventory completeness of the island, and (3) to locate a priori

Table 1 Estimated number of species at worldwide and European scales, and number of described species detailed for the whole Macaronesian region and their including archipelagos (Azores, Madeira, Selvagens, Canary Islands and Cape Verde)

\begin{tabular}{llll}
\hline Geographic region & Hornworts & Liverworts & Mosses \\
\hline World $^{\mathrm{a}}$ & 200 & $5-6 \times 10^{3}$ & $8-13 \times 10^{3}$ \\
Europe $^{\mathrm{b}}$ & 8 & 701 & 1,292 \\
Macaronesia $^{\mathrm{b}}$ & 6 & 235 & 551 \\
Azores $^{\mathrm{c}}$ & 6 & 155 & 283 \\
Madeira and Selvagens $^{\mathrm{d}}$ & 6 & 175 & 333 \\
Canaries $^{\mathrm{e}}$ & 6 & 141 & 352 \\
Cape Verde $^{\mathrm{f}}$ & 2 & 35 & 116 \\
\hline
\end{tabular}

Data sources: ${ }^{a}$ Hallingbäck and Hodgetts (2000), Goffinet and Shaw (2009); ${ }^{\text {b }}$ Hill et al. (2006), Söderström et al. (2007); ${ }^{\mathrm{c}}$ Gabriel et al. (2005), Söderström et al. (2007); ${ }^{\mathrm{d}}$ Sérgio et al. (2008); ${ }^{\mathrm{e}}$ GonzálezMancebo et al. (2008); ${ }^{\mathrm{f}}$ Patiño and González-Mancebo (2005) 
further survey areas to fill knowledge gaps efficiently. We hypothesise that temporal trends in new species inventories may be extrapolated to estimate the number of unrecorded bryophytes, and also that spatial trends of survey locations with new recorded species may be helpful to guide future surveys. Finally, we include a section discussing the limitations of our work and suggestions for further research.

\section{Methods}

Study area

The Azorean archipelago is located in the North Atlantic Ocean between $37-40^{\circ} \mathrm{N}$ latitude and $23-31^{\circ} \mathrm{W}$ longitude (Fig. 1) and the closest point to mainland Europe is around $1,400 \mathrm{~km}$. It is composed of nine volcanic islands of relatively recent origin (varying between 0.25 and $8 \mathrm{Myr}$, although most areas are less than $1 \mathrm{Myr}$ old). Terceira is the third largest island, with c. $402 \mathrm{~km}^{2}$ and a maximum altitude of $1,021 \mathrm{~m}$. The climate is temperate oceanic, characterised by mild temperatures, moderate to high rainfall, and high atmospheric humidity (Azevedo 1996). All these conditions favoured the maintenance of the subtropical evergreen laurel forests (laurisilva) recognisable from Tertiary deposits (5.3 Myr) in Europe (Axelrod 1975). Azorean laurisilva is characterised by the presence of low-statured, densely concentrated trees, dominated by Laurus azorica, Juniperus brevifolia and Ilex perado subsp. azorica, and contain some shrubs (Myrsine africana, Vaccinium cylindraceum) and a high diversity of ferns. Naturalised vegetation composed of Ericaceae species typically surrounds these areas. Unfortunately, the extent of native forests has decreased in every island and nowadays it occupies only around five percent of

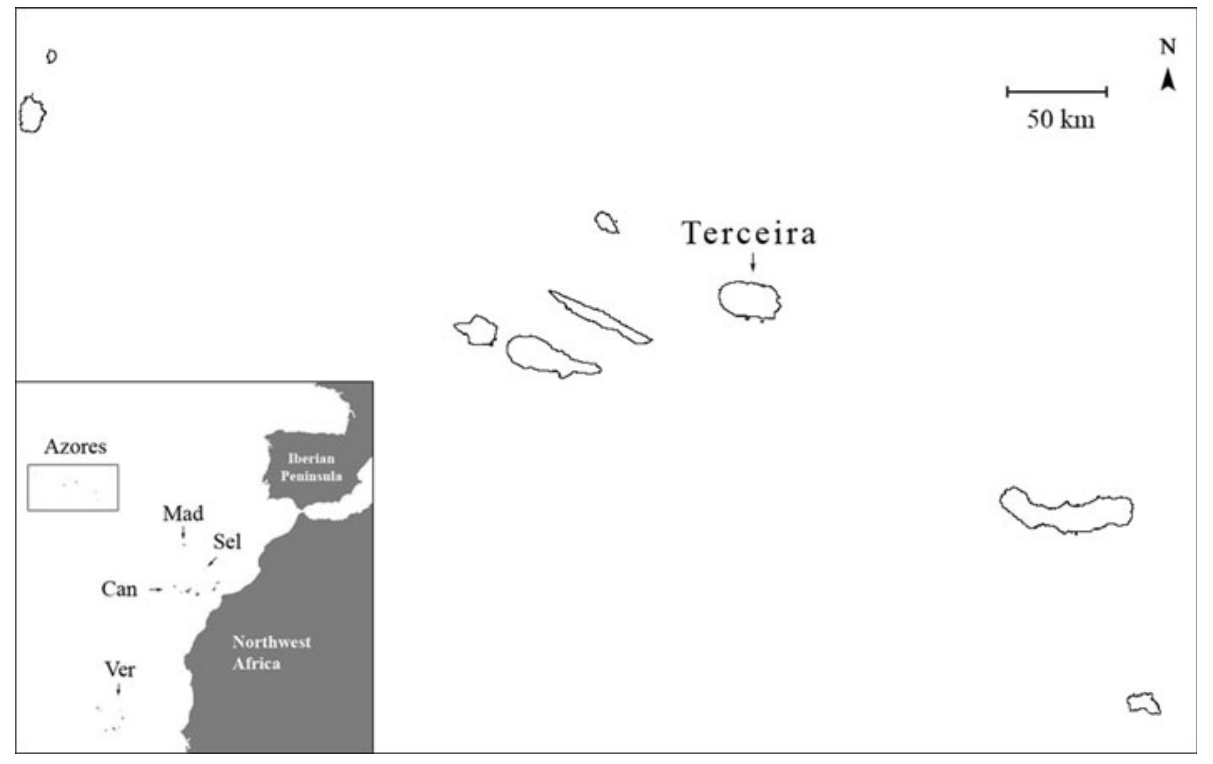

Fig. 1 Geographical location of Terceira Island in the Azorean archipelago. The reduced image shows the situation of the five Macaronesian archipelagos: Madeira (Mad), Selvagens (Sel), Canary Islands (Can), Cape Verde (Ver) and Azores 
the total area of Terceira, mostly located in the central part of the island (Gaspar et al. 2008). Since the first Portuguese settlements in the early fifteenth century, human activities have been increasing, causing a reduction of natural vegetation, with the progressive replacement of native forest species by exotics such as Cryptomeria japonica, Pittosporum undulatum and Eucalyptus spp., or by crop areas or cattle grasslands which represent most part of the actual landscape.

\section{Biological database}

We compiled all the known information on bryophytes distribution (starting on late XIX century publications), and it was then digitalised following a standard protocol. We examined about 200 bibliographic references as well as several electronic databases (see Supplementary Appendix S1), including a high proportion of unpublished data (around $45 \%$ of the total information), mainly referring to records preserved at the Herbarium of the University of the Azores (AZU). The following collection information was obtained for each species: year of collection, collector, locality, altitude and type of substratum (mainly soil, rock, bark and leaves). For our purposes, we considered that any variation in at least one of these database fields constituted a different database-record. We subsequently georeferenced sample localities at a $500 \mathrm{~m} \times 500 \mathrm{~m}$ UTM grid-cell resolution using the ATLANTIS-Tierra 2.0 software, and old site names were placed by experts. Survey localities were classified into four levels of precision: (A) localities from one to three neighbouring grid-cells (around $0.75 \mathrm{~km}^{2}$ ); (B) localities from four to 50 adjacent gridcells (a maximum area of $12.5 \mathrm{~km}^{2}$ ); (C) localities with more than 50 grid-cells (excluding 'island' level); and (D) island level. In this study, we considered a total of 246 localities of level A (corresponding to 5,893 database-records, around $72 \%$ of the used information) and 128 localities of level B (2,247 database-records), discarding all the data belonging to $\mathrm{C}$ and $\mathrm{D}$, the most imprecise levels (3,464 records). The rejection of such data implied loosing occurrence information of only 16 species not present in levels A and B, 13 of them $(81 \%)$ without information on their collecting date. Nomenclature followed the taxonomical standard of the recently published checklist of Azorean bryophytes (Gabriel et al. 2005), with some updates from Hill et al. (2006) and Söderström et al. (2007). Taxa below the subspecies category were not included. After cleaning and standardising all the information, the most updated database (May 2009) contained 8,140 records belonging to 348 species of 68 families, in 374 localities (962 grid-cells). This database is available upon request from Rosalina Gabriel (contact: rgabriel@uac.pt).

\section{Assessment of temporal trends}

We analysed historical trends in the inventorying of species by depicting the cumulative number of new recorded species that were added to the pool of all previously observed species over time. The temporal evolution of taxonomic inventories was described for each year of collection using all the available records from 1894 to 2006. We assessed temporal curves describing the accumulation of new recorded species for all bryophytes of Terceira Island, as well as separately for hornworts, liverworts and mosses. We calculated the rate of new recorded species over time as the slope of these accumulated curves, and we used an analysis of covariance (ANCOVA test) to compare the differences of such rates among taxonomic groups (only liverworts and mosses were taken into account due to the low sample size of hornworts $[n=4])$. 
We also described variations in the sampling process using the number of databaserecords as a surrogate for survey effort, which is an effective measure to compare heterogeneous information coming from different sources (Hortal et al. 2006; Lobo 2008). Firstly, we assessed the correlation between the number of new accumulated species over time and the increase of database-records, and then we estimated the sampling efficiency by calculating the number of database-records that were necessary to describe a species previously unknown to the Island (that is, the ratio between the number of database-records and the number of new inventoried species). We expect a decrease of sampling efficiency with time because, initially, the common species are rapidly collected, but as the inventory nears completion, it is more difficult to discover the remaining rarer taxa.

\section{Estimating inventory completeness}

We used the temporal species accumulation curves to estimate the theoretical total number of species that remain to be discovered. To do this, we fitted observed species accumulation data to parametric curves using the freeware Species Accumulation Functions (DíazFrancés and Soberón 2005). These curves assume that there is a high probability of adding new species early in the inventory (when few collectors have previously visited the area), but decreases over time as the number of species found increases. The curve follows a convex function until reaching an ideal asymptote of maximum species richness where the survey effort is almost infinite. The ratio between the observed and the so estimated species richness is a metric characterising inventory completeness. We estimated the theoretical maximum species richness according to two commonly used functions: Clench (Eq. 1) and exponential (Eq. 2). The formulas are given by:

$$
\begin{gathered}
S(t)=a t /(1+b t) \\
S(t)=(a / b) \cdot\left(1-e^{-b t}\right)
\end{gathered}
$$

where $S(t)$ is the accumulated number of species in $t$ years, $a$ and $b$ are the parameters to be estimated and $e$ is the base of the natural logarithms. The coefficient of determination $\left(R^{2}\right)$ was calculated to evaluate model performance.

Examining the spatial structure and habitat characteristics of data

We analysed whether the new recorded species occurred at random or, conversely, whether there was a spatial structure underlying the process. If the latter occurred, then it could be assumed that this trend would be the most favourable strategy to detect new species in the island in the future. To do this, we regressed the first dates of collection of each species against the geographical coordinates of the locality or localities where they were found. After standardising longitude and latitude (zero mean, one standard deviation), we performed a Trend Surface Analysis using a backward stepwise procedure with the nine terms of a third-order polynomial of these two spatial variables (see Legendre and Legendre 1998).

Similarly, we used a non-parametric Kruskal-Wallis ANOVA test with post-hoc multiple comparisons to assess whether the first year of species collections significantly differed between the dominant habitats in Terceira. We applied the Bonferroni correction for multiple testing. We assumed that habitats with more recently new recorded species would shelter a greater proportion of the unknown species. A map of land use was derived from aerial photography and fieldwork (F. Dinis, unpubl.; see also Borges et al. 2010) with 
additional information from DROTRH (2008). The map was provided as a $500 \mathrm{~m} \times 500 \mathrm{~m}$ raster layer that was processed using a geographic information system (IDRISI Kilimanjaro, Clark University 2003) to obtain the dominant habitat at the survey sites where each species was first collected. We established five main categories as the most relevant: 'native forests' (comprising both natural and secondary naturalised areas), 'exotic forests', 'intensive pastures' (under intensive management and sowed from 1 to 10 years intervals, characterised also by a poor vascular flora of five or fewer contributing species), 'semi-natural pastures' (created in the 1960s-1970s replacing native habitats and under low intensive management for more than 30 years, with a higher diversity of grasses and forbs, where grazing is primarily concentrated in the spring-summer), and 'social areas' (encompassing mostly urban zones, but also some industrial, crop and farming areas).

All statistical computations were performed by using the STATISTICA software (StatSoft Inc. 2007).

\section{Results}

How did the process of species inventorying change over time?

Survey effort in Terceira has been increasing from the first collections carried out more than one century ago (Fig. 2). Since then, about 40 collectors have visited the island and sampled 374 localities covering nearly a half of the island area. However, both the intensity and frequency of sampling were varied, and greatly depended on the time period. The mean number of database-records per year was $72.5 \pm 20.2$ (mean $\pm \mathrm{SE}$ ), oscillating from zero records (mostly prior to 1980) to a maximum of 1,137 (in 2003). The highest survey

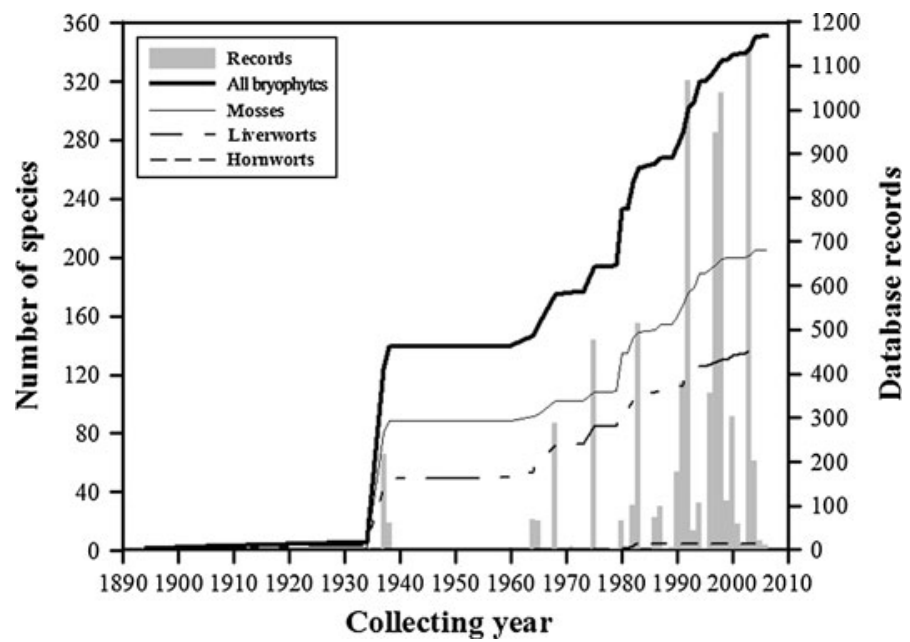

Fig. 2 Historical evolution of the total number of accumulated bryophyte species recorded in Terceira Island and the number of species belonging to Anthocerotopsida (horworts), Marchantiopsida (liverworts) and Bryopsida (mosses). Bars represent the temporal variation in the number of database-records 
effort was made during the last two decades, mainly thanks to the activity of resident taxonomists and ecologists. Three different phases can be clearly recognised in the inventorying process (Fig. 2): (i) a long period with low productivity from 1894 just until 1937, a year in which 118 new species inventoried were recorded for the island in almost 40 different places (around a third of all the species presently known); (ii) a second period that lacked surveys from 1938 until 1960, and (iii) the last phase from 1961 until the present, where there was a high increase in bryological activity, as shown by a mean rate of $4.8 \pm 1.2$ new species recorded per year. During this last period, there was a constant increase in the addition of new liverworts and mosses, with 139 and 205 species currently inventoried, respectively. With regard to hornworts, the four known species in the island were recorded in the 1980s, and no more additions have been observed during the last 30 years. By 1994, 90\% of all presently known species had been recorded.

The number of database-records per year was positively correlated with the number of new recorded species (Spearman rank correlation $r_{s}=0.88, n=111, P<0.001$ ), and the survey effort necessary to record a new species for the island followed a well-defined pattern (Fig. 3). Although it was possible to find new recorded species with a moderate survey effort (less than 25 database-records) during the whole period, the main temporal trend indicates that an increasingly survey effort will be required with time.

Liverworts and mosses followed a similar temporal pattern of increasing in the number of accumulated species (Pearson correlation $r=0.99, n=111, P<0.05$ ). However, the rate of new recorded species per year was significantly higher, on average, for mosses than for liverworts in both historical and current times. Before 1960, the mean rate of new recorded species per year for mosses was 1.4 and for liverworts 0.7 (ANCOVA test; $t=4.1, n=66, P<0.001)$. After 1960, the mean number of new recorded species per year for mosses was 2.6 and for liverworts was $2.1(t=22.3, n=44, P<0.001)$.

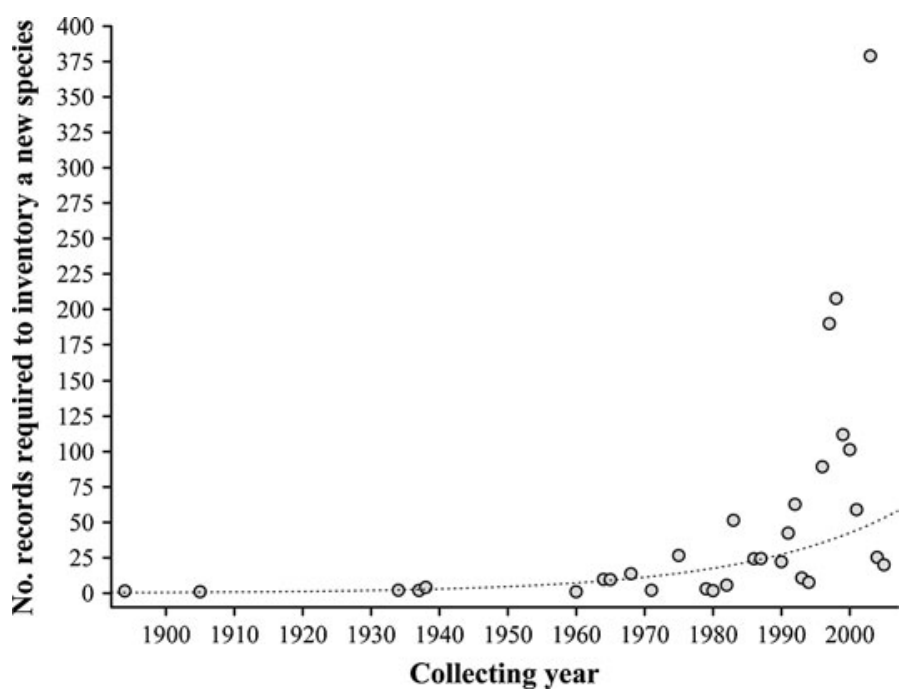

Fig. 3 Temporal evolution in the sampling efficiency of bryophytes measured as the number of databaserecords necessary to inventory a new unknown species for the island. The broken line shows the best fitting curve to the observed data using the lowess regression method 
How many bryophytes remain undiscovered in Terceira, and where should we look for them?

We only used the observed data after 1960 to avoid extrapolating the very bumpy accumulation curves before this date (Fig. 2). In all cases, predictions of species richness were highly variable depending on the fitting curve (Table 2, Appendix S2). Using the Clench model $\left(R^{2}=79.2 \%\right)$, around a third of the total species that theoretically exist in Terceira remain undiscovered. By contrast, using the exponential model $\left(R^{2}=76.0 \%\right)$ almost all species had been already found. Although the survey effort was approximately the same between liverworts and mosses (that is, the number of database-records per locality was not significantly different according to Mann-Whitney test: $U=36166.5, p=0.3, n_{1}$ (mosses) $=319, n_{2}$ (liverworts) $=239$ ), the number of species currently recorded was higher for mosses than for liverworts. According to these results, a theoretical maximum of 67 liverworts and 95 moss species could remain unknown.

Trend Surface Analysis results showed that only $20 \%$ of the variation in the first date of species collection is explained by spatial variables, indicating a slightly temporal western tendency in the location of recent discoveries. Before 1960, new recorded species were placed across a wide range of longitudes from east to west while, recently, they mainly appear toward the westernmost areas (not shown). This spatial pattern is related to the current land uses in such localities (Fig. 4). The first collecting year for each species significantly differed between habitats (Kruskal-Wallis test: $H=89.80, P<0.001$ ), probably because since their first record long ago, such localities have been highly modified due to land-use changes. Actually, of the 84 survey sites visited before 1960 (715 database-records), we can assume that 14 are currently semi-natural pastures (65 databaserecords) and three are exotic forests (54 database-records). In modern times, the majority of the new recorded species occurred in the laurisilva located in the central-west part of the island where the landscape was less modified; nevertheless more than a fifth of the species (c. 23\%) were found in exotic forests and more than a quarter (c. 30\%) were found in seminatural pastures (Fig. 4).

Table 2 Number of database-records and number of currently observed species obtained from the database of bryophytes' distribution in Terceira

\begin{tabular}{llll}
\hline & All bryophytes & Liverworts & Mosses \\
\hline $\begin{array}{l}\text { Database records } \\
\text { Observed richness }\end{array}$ & 8,140 & 4,425 & 3,658 \\
Clench model & 348 & 139 & 205 \\
Estimated richness & & & 300 \\
$R^{2}(\%)$ & 520 & 206 & 71.9 \\
Completeness (\%) & 79.2 & 87.0 & 68 \\
Exponential model & 67 & 67 & 208 \\
Estimated richness & & & 68.4 \\
$R^{2}(\%)$ & 352 & 142 & 99 \\
Completeness $(\%)$ & 76.0 & 84.0 & 98 \\
\hline
\end{tabular}

Species richness estimations were calculated as the asymptotic values of the temporal species accumulation curve using both Clench and exponential models (see Appendix S2), which allows to assess the percentage of observed species over the estimated ones (completeness). The $R^{2}$ values are given for each curve as a goodness-of-fit measure 
Fig. 4 a Dominant habitats of Terceira Island, and b betweenhabitat differences in the first collecting date of each described species. Habitat categories are: 'Social' (mostly urban areas), 'ExoFor' (exotic forests), 'NatFor' (native forests), 'IntPast' (intensive pastures) and 'SemiPast' (semi-natural pastures). The plot represents the 25 th and 75 th quartiles (boxes), the minimum and maximum scores (whiskers) and the median values (filled squares).

Categories with the same letter show statistically significant differences among all pairwise comparisons according to a posthoc Kruskal-Wallis ANOVA test. Bonferroni correction was applied to adjust the significance level for multiple testing $(P<0.005)$
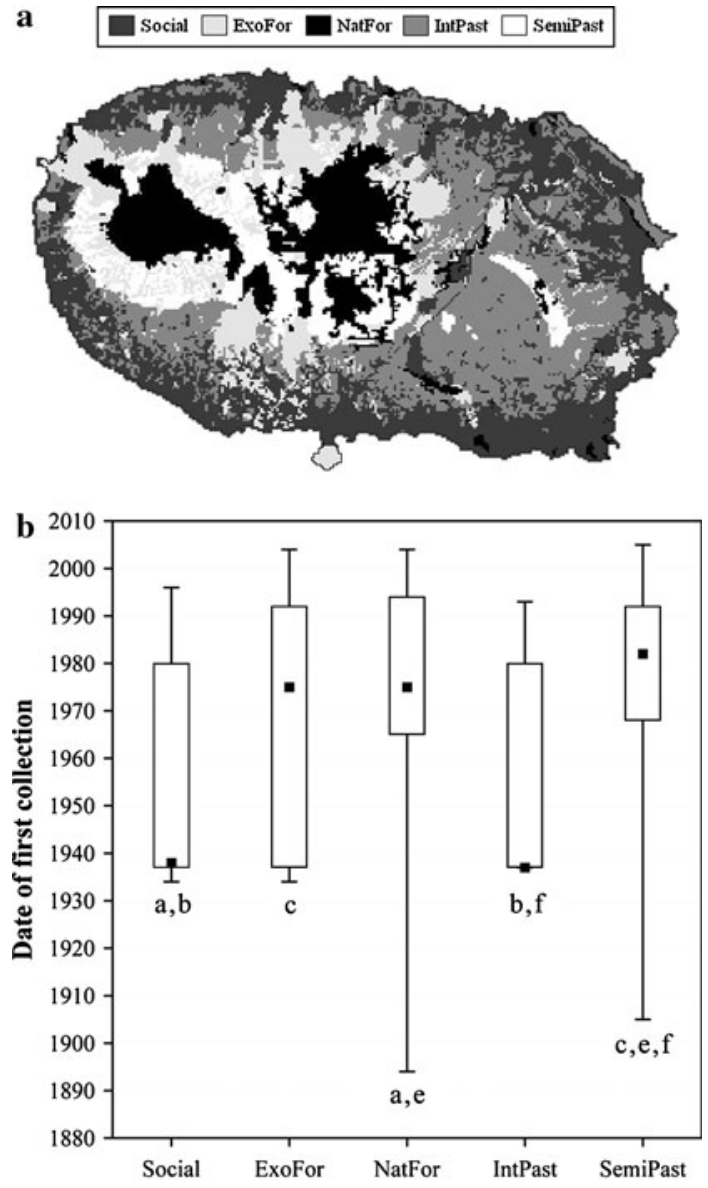

\section{Discussion}

The historical process of species discovery

Here we show how the species discovery process can be characterized using a complete compilation of all available taxonomic and distributional information on all the species of a region. Based on these data, the proportion of species that remain undiscovered can be estimated, and locations where new species are most likely to be found can be identified. Obviously, this study could not have been made without the prior knowledge provided by all the collectors and publishers of records. However, our data revealed that the sampling strategies used up to now have not been effective enough to represent the existing biodiversity, probably due to their different purposes and the uncoordinated character of field surveys, which were not specifically designed to unveil the biodiversity of the island (see e.g., Sastre and Lobo 2009). These quantitative approaches are thus useful to uncover, not only the lack of available information, but also the possible biases of previous collections. With this in mind, we offer some suggestions to improve the future efficiency of bryophyte 
inventorying in Terceira Island, which may be applicable particularly in remote areas, both in the Azores and elsewhere.

The Azorean Islands are a good case study for inventorying bryophytes due to their strongly oceanic environment, unique forest systems (unmodified by man until comparatively recent times), the high diversity of species from several biogeographical origins, and the recording tradition initiated in the late nineteenth century. The temporal trend of the species recorded in the Terceira Island shows a non-uniform pattern. Until 1960, the rate of new recorded species was highly intermittent. Most knowledge about the current flora was gathered in 1937 during the historical visits of the Swedish bryologist Herman Persson (116 recorded species) and Pierre and Valerie Allorge (80 species) (see Appendix S1). After a period of no visits, the consistent work of Erik Sjögren, beginning in 1965 and continued for 30 years, increased the recording intensity (e.g., Sjögren 1978). The regular additions from the 1960s onward (Fig. 2) were also a result of the work of other authors such as Crundwell in 1980 (Crundwell et al. 1994) and Gabriel in the 1990s (see e.g., Gabriel and Bates 2005). Sjögren, Crundwell and Gabriel recorded together 134 species, representing each one between 10 and $15 \%$ of all known species.

The more constant taxonomic and floristic research since 1960 also made possible the accomplishment of checklists. The first catalogue of species for Europe including the Azores appeared in 1981 (Corley et al. 1981), while a Macaronesian checklist of bryophytes was published in 1982 (Eggers 1982) and the first list specifically produced for the Azorean Islands was published in 2001 (Sjögren 2001). The latter was updated by Gabriel et al. in 2005, which was created using a comprehensive inventory of the terrestrial fauna and flora from the Azores (Borges et al. 2005). Additionally, much knowledge about the geographical distribution of bryophytes in the Azores originated from a thorough review of the taxonomic papers, including a significant amount of material collected in the last few years (AZU, UPS). All this information has been digitalised using ATLANTIS-Tierra 2.0 software, and most of the resulting distribution maps are available on-line through the Azorean Biodiversity Portal (http://www.azoresbioportal.angra.uac.pt/). To date, both initiatives on species taxonomy and geographical distribution are the most important contributions to the knowledge of the Azorean bryophyte diversity.

How much do we know, and how much remains to be discovered?

Terceira is one of the best-studied Azorean islands from the botanical point of view since it hosts the largest area of pristine native forests. Approximately $80 \%$ of the currently listed bryoflora in the archipelago is known on Terceira Island, representing almost $45 \%$ of the Macaronesian diversity (Table 1). Nevertheless, our results showed that the overall rate of new recorded bryophytes since 1960 (around five new species per year) has even increased in recent times: during the 1960 s this rate was $3.3 \pm 2.0$ species per year, but $6.4 \pm 1.6$ species per year in the 1990s. The rate of new recorded species was greater for mosses, probably because this is the most diverse taxonomical group. While the exponential model reveals a very high completeness value (99\%), according to the Clench model, the rising trend of recorded species over time is still far from reaching a clear stable plateau. The extrapolation of such accumulation curves showed that a possible maximum of 520 total species could exist in the island, which is $15 \%$ greater than the observed diversity in the entire archipelago (444 species) and two-thirds of the estimated total bryophytes of the island. As shown in Fig. 2, there has been a notorious rise in the number of new recorded species in the last decades, and only further studies will show how the slope of the curves will vary. In favour of the highest estimates is the fact that only half of the island's 
$500 \times 500 \mathrm{~m}$ grid-cells have been visited and less than $1 \%$ of them have reliable inventories (unpublished results). However, it must be noted that these predicted values could be erroneous, primarily due to the effect of the fitting-function used to extrapolate the shape of the curve (see Appendix S2), and also because the curves aggregate variation between taxa, sampling methods, and the spatial and temporal heterogeneity affecting the organisms (see Soberón and Llorente 1993). Although there are many types of fitting functions for species accumulation curves (e.g., Flather 1996), all of them suffer from the same problems. Besides, we only used data after 1960 to extrapolate the shape of the curves, and this implies losing occurrence information for 16 species that have not been found again after this date. Probably, the "real" number of species, although highly variable, is between the conservative predictions of the exponential function and those of the probably overestimated Clench curve. Since statistical extrapolation is always fraught with danger, we believe that such models provide a simplistic picture better aimed at providing insight into the main trends, rather than fixed numerical estimations. Thus, predictions should be necessarily validated or corrected with additional field and taxonomical work, which is already being undertaken.

To our knowledge, there are few studies on bryophytes that have addressed these topics. However, Callaghan and Ashton (2008) have recently published a comprehensive study to estimate the gaps of information and the completeness of distribution inventories by using high-resolution data compiled for northwest England. They expressly recognised that data from atlases generally lacked a systematic method for measuring the completeness of an inventory because the survey-effort unit is not recorded during surveys extending back several decades. Additionally, von Konrat et al. (2008) created an exhaustive global database uniting liverwort nomenclature, taxonomy and geography at a worldwide scale (around 60,000 preliminary records from over 600 publications) using global maps and geopolitical units for liverwort species, genera, and family richness. Although this is an important attempt to gather as much information as possible, they confirmed that no reliable quantitative data exists with which the global number of liverwort species can be estimated objectively. We believe that such studies are highly commendable, and we further add that exploring the existing data is a necessary step before analysing bryophyte diversity patterns.

Future perspectives for further research

Regardless of the estimated number of undiscovered species, it is clear that the previous taxonomic and floristic work was important and necessary to enhance the future completeness of the species inventory. In the beginning of the collecting process, it is easy to find new species. Over time, it becomes increasingly difficult because the species inventory is more complete and, consequently, more effort is required to find new records. However, presently, there are more taxonomical resources than in the past: the growing expertise, the possibility of making regular sampling campaigns and the ability to design better field surveys are likely to improve the sampling efficiency in the future. Besides, there exists a great determination to complete the biodiversity inventory of European territories (e.g., 2010 Target), which did not exist in the past, when the collection of "novelties" was one of the main purposes of the collectors' visits. Because our results indicate a strong relationship between the number of new-inventoried species and the number of databaserecords, it is clear that the higher the survey effort, the greater the number of recorded species. During the last 40 years a high recording intensity (7,756 database-records) enabled the discovery of approximately five species per year in Terceira; would a similar 
effort allow the recording of the remaining unknown species? Our results demonstrated that a greater survey effort is going to be required to add new species to the inventory. If we aim to accelerate species discovery, then as a general thumb rule we will need to improve the collection efficiency by designing surveys that take into account both the spatial and environmental gradients of the island, according to the patterns shown here. Although provisional, our results provide some basic recommendations on where further survey efforts should be focused.

In order to complete the bryophytes inventory in Terceira Island, surveys should henceforth be conducted in places with similar spatial and habitat characteristics as the ones where new species have been recently discovered. The observed spatial bias indicates that the zone of major interest for bryologists has traditionally been the central part of the island where the most luxuriant laurel forests are believed to remain from the Tertiary. In contrast, we show that the best regions to recent discoveries of new species are concentrated toward the westernmost extensive forests of Juniperus brevifolia and Laurus azorica inside the Caldeira de Santa Bárbara, an area which has also been recognised as a genuine bryologist's paradise (Frahm 2004) and is considered to be one of the most undisturbed native forests of the Azores (Cardoso et al. 2007). It is obvious that bryologists preferably collected in native forest environments (4,974 database-records, about $60 \%$ of all gathered information), and that this tendency will continue in the future. However, assuming that the current landscape has remained more or less constant since 1960-1970 (as indicated in aerial photographs), we observed that new species might also be found in other habitats types such as exotic forests and semi-natural grasslands. In fact, previous studies found that the exotic forests provide a home for several interesting Azorean bryophytes, especially, for the epiphytic flora (Bates 2000), and some surveys conducted on semi-natural pastures found several new species (Dias 1986; Sérgio et al. 1995; Bates and Gabriel 1997). Although recent studies also supported the idea that agricultural landscapes may have moderate to high bryophyte diversity (Porley 2000; Zechmeister et al. 2003), our results should be cautiously treated because this category (semi-natural pastures) includes currently abandoned pastures, now colonised by native Ericaceae species, as well as some species-rich peatlands, and we believe that both facts may be inflating these results.

In conclusion, this study aimed to suggest a useful way to address the difficulties of quantifying species diversity in a region, which can be combined with traditional methodologies to improve our overall knowledge. We emphasise that such approaches should be directed towards improving sampling surveys, and that they should especially focus on better understanding of global biodiversity patterns.

Acknowledgements We are very grateful to Berta Martins and Enésima Mendonça for their unconditional help with the ATLANTIS software. Thanks also to Fernando Pereira, who interpreted and placed most of collecting localities from old studies. SA is a $\mathrm{PhD}$ candidate from University of Azores and was supported by a grant from Direcção Regional da Ciência e Tecnologia dos Açores (M311/I009A/2005). PAVB and RG worked on this project under the DRCT projects M2.1.2/I/017/2007, M.2.1.2/I/003/2008 and the EU projects INTERREGIII B “ATLÂNTICO”(2004-2006) and BIONATURA (2006-2008).

\section{References}

Axelrod DI (1975) Evolution and biogeography of Madrean-Tethyan sclerophyll vegetation. Ann MO Bot Gard 62:280-334 
Azevedo EB (1996) Modelação do Clima Insular Escala Local. Modelo CIELO aplicado ilha Terceira. PhD Thesis, University of Azores, Angra do Heroísmo

Bates JW (2000) Introduction to the Azores and its Bryophytes. Bull Br Bryol Soc 76:21-23

Bates JW, Gabriel R (1997) Sphagnum cuspidatum and S. imbricatum ssp. affine new to Macaronesia, and other new island records for Terceira, Azores. J Bryol 19:645-648

Bebber DP, Marriott FHC, Gaston KJ, Harris SA, Scotland RW (2007) Predicting unknown species numbers using discovery curves. Proc R Soc B 274:1651-1658

Borges PAV, Cunha R, Gabriel R, Martins AF, Silva L, Vieira V (2005) A list of the terrestrial fauna (Mollusca and Arthropoda) and flora (Bryophyta, Pteridophyta and Spermatophyta) from the Azores. Direcção Regional do Ambiente and Universidade dos Açores, Horta, Angra do Heroísmo and Ponta Delgada

Borges PAV, Hortal J, Gabriel R, Homem N (2009) Would species richness estimators change the observed species area relationship? Acta Oecol 35:149-156

Borges PAV, Azevedo EB, Borba A, Dinis FO, Gabriel R, Silva E (2010) Ilhas Oceânicas. In: Pereira HM, Domingos T, Vicente L (eds) Portugal millenium ecosystem assessment. Escolar Editora, Lisboa, pp 461-508

Brose U, Martinez ND, Williams RJ (2003) Estimating species richness: sensitivity to sample coverage and insensitivity to spatial patterns. Ecology 84:2364-2377

Callaghan DA, Ashton PA (2008) Knowledge gaps in bryophyte distribution and prediction of speciesrichness. J Bryol 30:147-158

Cardoso P, Borges PAV, Gaspar C (2007) Biotic integrity of the arthropod communities in the natural forests of Azores. Biodivers Conserv 16:2883-2901

Casas C, Brugues M, Cros RM, Sérgio C (1985) Cartografia de Briòfitos. Península Ibèrica i les Illes Baleares, Canàrias, Açores i Madeira. I. Institut d'estudis Catalans, Barcelona

Casas C, Brugues M, Cros RM, Sérgio C (1989) Cartografia de Briòfitos. Península Ibèrica i les Illes Baleares, Canàrias, Açores i Madeira. II. Institut d'estudis. Catalans, Barcelona

Casas C, Brugues M, Cros RM, Sérgio C (1992) Cartografia de Briòfitos. Península Ibèrica i les Illes Baleares, Canàrias, Açores i Madeira. III. Institut d'estudis. Catalans, Barcelona

Casas C, Brugues M, Cros RM, Sérgio C (1996) Cartografia de Briòfitos. Península Ibèrica i les Illes Baleares, Canàrias, Açores i Madeira. IV. Institut d'estudis. Catalans, Barcelona

Clark University (2003) Idrisi Kilimanjaro. GIS software package, Worcester, MA, USA

Colwell RK, Coddington JA (1994) Estimating terrestrial biodiversity through extrapolation. Philos Trans R Soc Lond B Biol Sci 345:101-118

Corley MFV, Crundwell AC, Düll R, Hill MO, Smith AJE (1981) Mosses of Europe and the Azores; an annotated list of species, with synonyms from the recent literature. J Bryol 11:609-689

Crundwell AC, Greven HC, Stern RC (1994) Some additions to the bryophyte flora of the Azores. J Bryol 18:329-337

Curtis TP, Sloan WT, Scannell JW (2002) Estimating prokaryotic diversity and its limits. Proc Natl Acad Sci USA 99:10494-10499

Dias E (1986) Estudo Bio-Ecológico da Bacia da Lagoa do Negro. Relatórios e Comunicações do Departamento de Biologia da Universidade dos Açores 16:1-131

Díaz-Francés E, Soberón J (2005) Statistical estimation and model selection of species-accumulation functions. Conserv Biol 19:569-573

DROTRH (2008) Carta de ocupação do solo da região Autónoma dos Açores - Projecto SUEMAC. Secretaria Regional do Ambiente, Direcção Regional do Ordenamento do território e dos. Recursos Hídricos, Ponta Delgada

Eggers J (1982) Artenliste der Moose Makaronesiens. Cryptogamie, Bryologie et Lichénologie 3:283-335

Flather CH (1996) Fitting species-accumulation functions and assessing regional land use impacts on avian diversity. J Biogeogr 23:155-168

Frahm J-P (2004) A guide to bryological hotspots in Europe. Arch Bryol 3:1-14

Gabriel R, Bates JW (2005) Bryophyte community composition and habitat specificity in the natural forests of Terceira, Azores. Plant Ecol 177:125-144

Gabriel R, Schumacker R, Sérgio C, Frahm J-P, Sousa E (2005) List of bryophytes (Bryophyta). In: Borges PAV, Cunha R, Gabriel R, Martins AF, Silva L, Vieira V (eds) A list of the terrestrial fauna (Mollusca and Arthropoda) and flora (Bryophyta, Pteridophyta and Spermatophyta) from the Azores. Direcção Regional do Ambiente and Universidade dos Açores, Horta, Angra do Heroísmo and Ponta Delgada, pp 69-113

Gaspar C, Borges PAV, Gaston KJ (2008) Diversity and distribution of arthropods in native forests of the Azores archipelago. Arquipélago. Life Mar Sci 25:1-30

Gaston KJ (1991) The magnitude of global insect species richness. Conserv Biol 5:283-296 
Gaston KJ (1996) Biodiversity: a biology of numbers and difference. Blackwell Science, California

Goffinet B, Shaw AJ (2009) Bryophyte biology. Cambridge University Press, Cambridge

González-Mancebo JM, Romaguera F, Ros RM, Patiño J, Werner O (2008) Bryophyte flora of the Canary Islands: an updated compilation of the species list with an analysis of distribution patterns in the context of the Macaronesian Region. Cryptogamie Bryologie 29:315-357

Gotelli NJ, Colwell RK (2001) Quantifying biodiversity: procedures and pitfalls in the measurement and comparison of species richness. Ecol Lett 4:379-391

Hallingbäck T, Hodgetts N (2000) Status survey and conservation action plan for bryophytes: mosses, liverworts and hornworts. IUCN/SSC. Bryophyte Specialist Group, IUCN, Gland, Switzerland and Cambridge, United Kingdom

Hill MO, Preston CD, Smith AJE (1991-1994) Atlas of the bryophytes of Britain and Ireland, vol 1-3. Colchester, Harley

Hill MO, Bell N, Bruggeman-Nannenga MA, Brugues M, Cano MJ, Enroth J, Flatberg KI, Frahm JP, Gallego MT, Garilleti R, Guerra J, Hedenäs L, Holyoak DT, Hyvönen J, Ignatov MS, Lara F, Mazimpaka V, Muñoz J, Söderström L (2006) An annotated checklist of the mosses of Europe and Macaronesia. J Bryol 28:198-267

Hortal J, Borges PAV, Gaspar C (2006) Evaluating the performance of species richness estimators: sensitivity to sample grain size. J Anim Ecol 75:274-287

Kadmon R, Farber O, Danin A (2004) Effect of roadside bias on the accuracy of predictive maps produced by bioclimatic models. Ecol Appl 14:401-413

Legendre P, Legendre L (1998) Numerical ecology. Elsevier, Amsterdam

Lobo JM (2008) Database records as a surrogate for sampling effort provide higher species richness estimations. Biodivers Conserv 17:1572-9710

Magurran AE (2004) Measuring biological diversity. Blackwell Science, Oxford

May RM (1988) How many species are there on Earth? Science 241:1441-1449

May RM (1990) How many species? Philos Trans R Soc Lond B Biol Sci 330:292-304

Médail F, Quézel P (1999) Biodiversity hotspots in the Mediterranean Basin: setting global conservation priorities. Conserv Biol 13:1510-1513

Mueller GM et al (2007) Global diversity and distribution of macrofungi. Biodivers Conserv 16:37-48

Myers N, Mittermeier RA, Mittermeier CG, Foseca GAB, Kent J (2000) Biodiversity hotspots for conservation priorities. Nature 403:853-859

Patiño J, González-Mancebo JM (2005) Briófitos. In: Arechavaleta M, Zurita N, Marrero MC, Martín JL (eds) Lista preliminary de especies silvestres de Cabo Verde (hongos, plantas y animals terrestres). Consejería de Medio Ambiente y Ordenación Territorial, Gobierno de Canarias, pp 69-113

Pautasso M, McKinney ML (2007) The botanist effect revisited: plant species richness, county area, and human population size in the United States. Conserv Biol 21:1333-1340

Pimm LP, Raven P (2000) Extinction by numbers. Nature 403:843-845

Porley RD (2000) Bryophytes of arable fields: current state of knowledge and conservation. In: Wilson P, King M (eds) Fields of vision: a future for Britain's arable plants. Plantlife, London, pp 8-19

Rull V (2008) Speciation timing and neotropical biodiversity: the Tertiary-Quaternary debate in the light of molecular phylogenetic evidence. Mol Ecol 17:2722-2729

Sánchez-Fernández D, Lobo JM, Abellán P, Ribera I (2008) Bias in freshwater biodiversity sampling: the case of Iberian water beetles. Divers Distrib 14:754-762

Sastre P, Lobo JM (2009) Taxonomist survey biases and the unveiling of biodiversity patterns. Biol Conserv 142:462-467

Scotland RW, Wortley AH (2003) How many species of seed plants are there? Taxon 52:101-104

Sérgio C, Gabriel R, Dias E (1995) Novos musgos para a flora da ilha Terceira (Açores). In: Notulae Bryoflorae Macaronesicae III. Revista de Biologia (Lisboa), vol 15, pp 187-188

Sérgio C, Sim-Sim M, Fontinha S, Figueira R (2008) List of bryophytes (Bryophyta). In: Pav Borges, Abreu C, Aguiar AMF, Carvalh P, Jardim R, Melo I, Oliveira P, Sérgio C, Serrano ARM, Vieira EP (eds) A list of the terrestrial fungi, flora and fauna of Madeira and Selvagens archipelagos. Direcção Regional do Ambiente da Madeira and Universidade dos Açores, Funchal and Angra do Heroísmo, pp 143-156

Sjögren E (1978) Bryophyte vegetation in the Azores Islands. Memórias da Sociedade Broteriana 26:1-273

Sjögren E (2001) Distribution of Azorean bryophytes up to 1999, their island distribution and information on their presence elsewhere, including Madeira and the Canary Islands. Boletim do Museu Municipal do Funchal, Sup 7:1-89

Soberón J, Llorente J (1993) The use of species accumulation functions for the prediction of species richness. Conserv Biol 7:480-488

Soberón J, Llorente J, Oñate L (2000) The use of specimen-label databases for conservation purposes: an example using Mexican Papilionid and Pierid butterflies. Biodivers Conserv 9:1441-1466 
Söderström L, Urmi E, Váňa J (2007) The distribution of Hepaticae and Anthocerotae in Europe and Macaronesia-Update 1-427. Cryptogamie, Bryologie 4:299-350

StatSoft Inc. (2007) STATISTICA (data analysis software system), version 8.0. www.statsoft.com

Vanderpoorten A, Rumsey FJ, Carine MA (2007) Does Macaronesia exist? Conflicting signal in the bryophyte and pteridophyte floras. Am J Bot 94:625-639

von Konrat M, Renner M, Söderström L, Hagborg A, Mutke J (2008) Early land plants today: liverwort species diversity and the relationship with higher taxonomy and higher plants. Fieldiana Bot 47:91-104

Walther BA, Moore JL (2005) The concepts of bias, precision and accuracy, and their use in testing the performance of species richness estimators, with a literature review of estimator performance. Ecography 28:815-829

Wilson EO (1988) The current state of biological diversity. In: Wilson EO (ed) Biodiversity. National Academic Press, Washington, pp 3-18

Zechmeister HG, Tribsch A, Moser D, Peterseil J, Wrbka T (2003) Biodiversity 'hot spots' for bryophytes in landscapes dominated by agriculture in Austria. Agric Ecosyst Environ 94:159-167

Zurita N, Arechavaleta M (2003) Banco de datos de Biodiversidad de Canarias. Boletín de la Sociedad Entomológica Aragonesa 32:293-294 